\title{
Halász Vendel \\ Az egyéb érdekeltek jogi védelme az Európai Unió vállalatfelvásárlási szabályozásában
}

\section{Stakeholders' Legal Protection in the European Union's Regulation of Corporate Takeover}

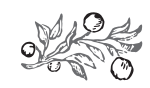

\section{Összefoglalás}

A vállalatfelvásárlások számos előnyös hatást fejthetnek ki egy gazdaságban. Ugyanakkor felmerülnek olyan aggályok is, hogy bizonyos esetekben az ilyen ügyletekben megjelenô részvényesi profit más társaságban jelen lévô érdekcsoportok (egyéb érdekeltek) költségére valósulhat meg. A tanulmány elemzi az Európai Unió vállalatfelvásárlási szabályozásában a részvényesi, illetve egyéb érdekelti érdekek védelmének eszközeit és módját. Ennek során megállapítja, hogy a céltársaságok részvényeseinek (akik jellemzôen az ilyen ügyletekkel komoly nyereséget tudnak elérni) védelmét megfelelốen biztosítja az uniós jog. Ugyanakkor az egyéb érdekeltek érdekei csorbát szenvedhetnek a szabályozási rendszer alapján, és ez hátrányosan érintheti a társadalmat. A szerzô viszont csak olyan vállalatfelvásárlási ügyletek létrejöttét látja optimálisnak, melyek valós társadalmi hasznot (is) jelentenek, és álláspontja szerint a szabályozási rendszernek is ez irányba kellene elmozdulnia.

Journal of Economic Literature (JEL) kódok: G34, G1

Kulcsszavak: vállalatfelvásárlás, részvényesi érdek, stakeholderelmélet

Dr. Halász Vendel PhD, óraadó, Pécsi Tudományegyetem Állam- és Jogtudományi Kar, Gazdasági és Kereskedelmi Jogi Tanszék (halasz.vendel@ gmail.com). 
Halász Vendel: Az egyéb érdekeltek jogi védelme az Európai Unió vállalatfelvásárlási...

\section{Summary}

Corporate takeovers may have numerous beneficial effects on the economy. However, concerns also emerge that in some cases the shareholders' profit on such transactions may be realized at the expense of other corporate constituencies (stakeholders). This study analyses the means and methods of shareholder and stakeholder protection in the European takeover legislation. The conclusion is that the interests of the target company's shareholders (who usually realise a significant profit on takeover transactions) are properly guaranteed by European Union law. However, stakeholder interests may be jeopardized under the current regulatory system, and this may adversely affect the society. The author only considers corporate takeover transactions as optimal if they (also) provide genuine social benefit. In the author's view, the regulatory system should also move towards this concept.

Journal of Economic Literature (JEL) codes: G34, G1

Keywords: corporate takeovers, interests of stakeholders, theory of stakeholder

\section{A VÁlLALATFELVÁSÁRLÁSOKRÓL}

A vállalatfelvásárlás általában egy olyan részvényvásárlási ajánlatot jelent, ahol a részvényeket megszerezni kívánó társaság (ajánlattevô) a céltársaságban irányító részesedést megtestesítô részvénypakettet szerez meg. Ez általában több mint 50\%-át jelenti a kibocsátott részvényeknek (Brudney-Chirelstein, 1974:297, Tuchinsky, 2007:694). A céltársaság részvényeinek megszerzésére irányuló ajánlat rendszerint a piaci ár fölött történik (Brown, 1970:517-518). Ha az ajánlat bejelentésekor az ajánlattevố nem rendelkezik a céltársaság menedzsmentjének támogatásával, akkor az ajánlatot ellenségesnek szokták minôsíteni. Ha az ajánlattevố bírja a céltársaság menedzsmentjének támogatását, akkor az ajánlat baráti (Tuchinsky, 2007:694; Hannes, 2003:1909-1910; Halász-Kecskés, 2011:368).

A vállalatfelvásárlások számos előnyös hatást fejthetnek ki a vállalati szférában: például azokhoz allokálhatják az erôforrásokat, akik a leghatékonyabban képesek azokat felhasználni, továbbá szinergiákat hozhatnak létre két társaság között. Szintén fegyelmezhetik a nem kellóen elôvigyázatos vagy nem megfelelôen múködố vállalati vezetést. Kiküszöbölhetik a piac tökéletlen múködésének következményeit, mely a társaság papírjainak alulárazottságában ölthet testet.

Ugyanakkor veszélyeket is hordozhatnak egy céltársaság, illetve a gazdasági rendszer számára: például egyes esetekben a menedzsment pusztán öncélú, „vállalatbirodalom” felépítésére irányuló törekvéseit szolgálhatják. A különbözô kizsákmányoláselméletek alapján pedig az ajánlattevố részvényesei tehetnek szert (a céltársaság részvényeinek szisztematikus alulértékelését vagy az egyéb érdekeltek helyzetét kihasználva) nyereségre a céltársaság részvényeseinek vagy az egyéb érdekelteknek ${ }^{1}$ a rovására. Ebbôl azt a következtetést vonhatjuk le, hogy a vállalatfelvásárlás egyszer értéket 
teremthet, más alkalommal viszont lehetséges, hogy csak újra elosztja azt. Szabályozói szempontból - bizonyos feltételek mellett - az értékteremtést támogatni látszik célszerûnek, míg az érték-újraelosztást ellenezni (Coffee, 1984:1167-1169, 1173-1174; Kecskés-Halász, 2013:399; Magnuson, 2009:208-210; Romano, 1992:119-181; Halász-Kecskés, 2011:369).

A 2008-ban kezdődött globális pénzügyi és gazdasági válságot követôen, napjainkra a nemzetközi részvénypiacok magukhoz tértek, a fóbb amerikai tőzsdei indexek pedig új magasságokba emelkedtek, és az előrejelzéseket készító elemzốk nagyrészt egyetértenek abban, hogy a felíveló piaci trend folytatódik 2017-ben is (Oyedele, 2016).

Nem meglepó, hogy az egyesülések és vállalatfelvásárlások piacán is meglehetős aktivitás figyelhetô meg. A 2015-ös évben például a bejelentett globális egyesülési és vállalatfelvásárlási ügyletek összértéke új rekordot állított fel, ugyanis mintegy 4,6 billió dollárt tett ki. Az egyesülési és vállalatfelvásárlási ügyletek volumene 2016-ban is igen jelentôs maradt, és elérte a mintegy 3,6 billió dollárt. Ezen erôteljes trend folytatódására lehet számítani 2017-ben is (Fontanella-Khan-Massoudi, 2015).

\section{A RÉSZVÉNYESI ÉRDEK ÉS ANNAK VÉDELME A VÁLLALATFELVÁSÁRLÁSI HELYZETEKBEN}

A vállalatfelvásárlások során a céltársaságok részvényesei általában jelentôs azonnali hozamban részesülnek (Cremers et al., 2009:1409-1410). A vállalatfelvásárlási tevékenység kapcsán az Egyesült Államokban e témában végzett kutatásokból azt a következtetést vonták le, hogy az ajánlattevôk komoly felárat (prémium) fizetnek ki ezeknek a részvényeseknek. Ezek a következtetések azért is mérvadónak tekinthetôk, hiszen ott már több mint fél évszázada e tôkepiaci tranzakciók a tudományos kutatások homlokterében állnak. Például a prémium átlagos mértéke a negyedik (amerikai) vállalatfelvásárlási hullám során, az 1980-1989 szeptemberéig terjedó időszakban a piaci árhoz képest 36\% és 71\% között alakult (az adott évtól függóen) (Anjier, 1991:586-587). Michael C. Jensen professzor a vállalatfelvásárlási felár mértékérôl szóló, 1988-as kutatásában kifejtette, hogy az átlagosan meghaladja a 30\%-ot (Fitzgibbon, 2010:57; Jensen, 1988:21-22). Szintén a vállalatfelvásárlások elônyös hatásaihoz sorolható, hogy a vállalatok feletti irányítás megszerzésének lehetôsége alapvetôen emelheti a részvények piaci értékét (Fitzgibbon, 2010:52, 56-57; Enriques, 2004:453). (Az ajánlattevô társaság részvényesei nem részesülnek ugyanakkor ilyen mértékú hozamban. Elméletben bizonyos szintú nyereségnek esetükben is kimutathatónak kellene lennie. Ők ugyanakkor - számos okból - akár veszteseivé is válhatnak a vállalatfelvásárlási tranzakcióknak.)

Az Európai Unióban a vállalatfelvásárlási jognak két jogforrási szintjét különíthetjük el. A vállalatfelvásárlási szabályozás közösségi szintú forrását és ezáltal a tagállamok jogi szabályozásának keretét a nyilvános vételi ajánlatról szóló 2004/25/EK irányelv (vállalatfelvásárlási irányelv) jelenti (Ferrarini-Miller, 2009:311-312). Erre épül a tagállamok által elfogadott szabályozás, melyet legkésôbb 2006. május 20-ig harmonizálni kellett az irányelvvel (Zwecker, 2012:234). Jelen tanulmányban fơként az irányelv szabályozásának bemutatására szorítkozom. 
Halász Vendel: Az egyéb érdekeltek jogi védelme az Európai Unió vállalatfelvásárlási...

A céltársaság részvényeseinek érdekeit az Európai Unió közösségi (és tagállami) szintû szabályozása hatékony védelemben részesíti. Az Európai Unióban vállalatfelvásárlások esetén a részvényesek védelmére szolgáló legfontosabb mechanizmus az irányítást biztosító részesedés megszerzésekor érvényesülő, ún. kötelezô nyilvános vételiajánlat-tételi szabály (Magnuson, 2009:219-220). Hasonlóképp kiemelhetjük a részvényesek számára a vállalatfelvásárlás során kifizetendő „méltányos árra” vonatkozó szabály fontosságát. Az irányelv alapján, vállalatfelvásárlás esetén, a társaságból való kiszállás lehetôségét valamennyi részvénybirtokos számára méltányos ellenérték fizetése mellett kell biztosítani ${ }^{2}$ (kivéve a szavazati joggal nem rendelkezô részvényeseket). ${ }^{3}$ Ez hozzájárul a befektetôk és a tôkepiacok magabiztosságának növeléséhez, hiszen a vállalat feletti irányításért kifizetett felárat (amely e szabályozás hiányában jelentôs mértékben a domináns részvénytulajdonos egyéni haszna lehetett) szétosztják valamennyi részvényes számára. Erre azért van lehetőség, mert a kötelezô nyilvános vételiajánlat-tételi szabály elzárja az irányító részesedést biztosító részvénypakettekkel való kereskedés útját (mivel ez a vállalat feletti irányítás megváltozását jelenti, és valamennyi részvényre kiterjedó, kötelezô nyilvános vételiajánlat-tételt von maga után), mely a leggyakoribb formája volt a vállalatok feletti irányítás megváltoztatásának Európa nagy részén (Goergen-Martynova-Renneboog, 2005:6-13; Berglöf-Burkart, 2003:175, 196-198; EC, 2007).

A szórt tulajdonosi struktúrában jelentkezó káros ajánlattételi technikákra (ún. részleges, illetve két lépésben megvalósuló ajánlatok) is hatékony ellenszert jelent a kötelezô ajánlattételt előíró szabály (Kecskés, 2011:3-15). Az eljárás lefolytatására vonatkozó (vételi ajánlat elfogadására nyitva álló időszak) és a céltársaság részvényeseinek megfeleló informáltságát biztosító (az ajánlatokra vonatkozó információ, vételi ajánlat közzététele) elôírások szintén fontos garanciális elemei az uniós szabályozásnak.

A céltársaság igazgatótanácsa és részvényesei között vállalatfelvásárlási helyzetben kialakuló érdekellentétet (hiszen míg vállalatfelvásárlások esetén az igazgatók elsôsorban pozíciójuk megtartásában, addig a céltársaság részvényesei a felvásárlás során elérhetô profitban érdekeltek) is a céltársaság részvényesei szempontjából megnyugtatóan rendezte az Európai Unió vállalatfelvásárlási irányelve, hiszen - fốszabályként - a vállalatfelvásárlási irányelv az ún. semlegességi (neutralitási) szabályban határozza meg az igazgatók által követendó magatartást (McCord, 1984:491; Chatterjee-HarrisonBergh, 2002:89; Fitzgibbon, 2010:55). A vállalatfelvásárlási irányelv 9. cikke ugyanis kimondja, hogy az ajánlattételrôl szóló döntésrôl (vagy az ajánlattételi szándékról) való tudomásszerzés és az ajánlat lezárása (vagy az ajánlat hatálytalanná válása) között a céltársaság igazgatótanácsának (ügyviteli vagy irányító szervének) meg kell szereznie a részvényesek közgyúlésének kizárólag e célból adott elốzetes felhatalmazását, ${ }^{4}$ bármely olyan intézkedés - más ajánlatok keresése kivételével - elôtt, ami az ajánlattételi eljárás megzavarását eredményezheti. A felhatalmazás megszerzéséig pedig semlegességre van kötelezve (a versengó ajánlatok keresését leszámítva) (Zinser, 2003; Menjucq, 2006:229-230; Edwards, 2004:435-436). Így minden védekezố intézkedéshez szükséges a részvényesek eloozetes felhatalmazása, jóváhagyása, beleegyezése. Az irány- 
elv 12. cikkének (Választható szabályozások) (1) bekezdése alapján a tagállamok jogosultak arra, hogy az irányelv hatálya alá tartozó azon vállalatokat, amelyeknek létesító okirat szerinti székhelye a területükön van, mentesítsék a semlegességi szabály ${ }^{5}$ alkalmazása alól. ${ }^{6}$ Így a semlegességi szabály alkalmazása nem kötelezố az irányelv alapján. Ugyanakkor a tagállamok többsége alkalmazza azt. ${ }^{7}$

A fentieket figyelembe véve elmondható, hogy az irányelv (és annak szabályait a nemzeti jogba átültetô és gyakran kiegészítô nemzeti jogalkotás) erôteljes védelemben részesíti a céltársaságok részvényeseinek érdekeit az Európai Unióban (Halász, 2015:77-246).

\section{A VÁllalatfelvásárlási ÜGYLETEK LEHETSÉgeS HATÁsa AZ EGYÉB ÉRDEKELTEKRE}

A felelős társaságirányítás korszerú, 21. századi megközelítésében a részvényesi érdekek fontosságának elismerése mellett nem tekinthetünk el a társaságokkal kapcsolatban álló egyéb érdekeltek szerepének hangsúlyozásától sem. Fontos kérdés ugyanakkor annak meghatározása, hogy egy társaság tevékenységéhez kapcsolódóan kiket tekinthetünk érdekelteknek. E kérdéskört némiképp leegyszerúsítve arra a következtetésre lehet jutni, hogy az egyéb érdekeltek érdekeit figyelembe vevô elmélet (stakeholder-elmélet) alapján, a legfontosabb ilyen érdekeltek a munkavállalók, a hitelezôk, a beszállítók, a fogyasztók, és a - társaság múködésével érintett - helyi közösségek. ${ }^{8}$ A vállalatfelvásárlások hatásai kapcsán azonban megjelenhet még figyelembe vehetô érdekként egy adott állam, nemzet gazdasága is, illetve ezzel párhuzamosan a kormányzati érdek (Zhao, 2014:16). ${ }^{9}$

Alapvetô probléma, hogy korábban sem volt, és tulajdonképpen jelenleg sincs egyértelmú álláspont arra vonatkozóan az akadémiai és az üzleti szektor szereplôi között, hogy milyen hatást tulajdonítsunk a vállalatfelvásárlási ügyleteknek. Nincs széleskörúen elfogadott konszenzus abban, hogy egyáltalán keletkezik-e érték, és ha igen, akkor az honnan származik egy vállalatfelvásárlási tranzakcióban (Anjier, 1991:564; ShleiferVishny, 1998:15-16).

Bár általában a céltársaság részvényesei jelentôs mértékben profitálni tudtak a vállalatfelvásárlásokból és a vállalatiszerkezet-átalakításokból, a részvényesi jólétet korántsem azonosíthatjuk a társadalmi jóléttel. Fennáll ugyanis a veszélye, hogy a részvényesek előnyszerzése - legalábbis részben - más, társaságban jelen lévő érdekcsoportok költségére valósulhat meg (ideértve, kiemelten a munkavállalókat és a hitelezôket). ${ }^{10}$ A vállalatfelvásárlás során a részvényeseknek fizetett felár egy része abból származhat, hogy a társaságban jelen lévő más érdekelti csoportoktól a részvényesi csoport irányába értékátcsoportosítás történik (McDaniel, 1991:124; Bebchuk, 2002:1021-1022).

Richard A. Booth ${ }^{11}$ professzor szerint is a vállalatfelvásárlási szabályozás egy fontos kérdése, hogy a részvényeseknek a vállalatfelvásárlás során fizetett prémium forrása honnan eredeztethetô. Az egyik alternatíva, hogy a társaság vezetésével kapcsolatban jobb elképzelésekkel rendelkezô ajánlattevô meg kívánja osztani az így keletkezô hasznot (ami helyes) a céltársaság részvényeseivel. A másik lehetôség viszont az, hogy a 
Halász Vendel: Az egyéb érdekeltek jogi védelme az Európai Unió vállalatfelvásárlási...

részvényeseknek kifizetett felárat néha (vagy esetleg gyakran) az ajánlattevô abból a tervezett megtakarításból fizeti ki, amit a menedzserekkel, beszállítókkal, fogyasztókkal, munkavállalókkal kötött szerzôdések újratárgyalásával és a korábbi megállapodásoknál kedvezôtlenebb feltételek kialakításával ér el (Booth, 1989:125-127). Ez pedig minden bizonnyal hátrányosan érinti azt a közösséget, ahol a céltársaság múködik.

Andrei Shleifer ${ }^{12}$ és Lawrence H. Summers ${ }^{13}$ közgazdászprofesszorok úgy érvelnek, hogy az ellenséges vállalatfelvásárlások lehetôvé tehetik a részvényeseknek, hogy „,kisajátítsák" az egyéb érdekeltek vagyonát (jólétét), és az ilyen vállalatfelvásárlások több értéket oszthatnak újra, mint amennyit teremtenek (Shleifer-Summers, 1988:33-56). Kiemelik, hogy az egyéb érdekeltektôl (pl. munkavállalók, beszállítók) a részvényesek irányába megnyilvánuló értékátcsoportosítások a vállalatfelvásárlási prémium jelentôs részét tehetik ki (Shleifer-Summers, 1988:53; McDaniel, 1991:125-126).

Lucian A. Bebchuk ${ }^{14}$ professzor szerint a társaságok eszközei feletti hatékony piac kialakulásához az egyik követelmény az externáliák hiánya, illetve hogy ily módon a vállalatfelvásárlások során a részvényesek által elért nyereség valós (nettó) társadalmi hasznot jelentsen. Tehát ez az elônyszerzés ne harmadik felek költségére valósuljon meg (Bebchuk, 1985:1693-1808, 1792; McDaniel, 1991:129). Egy racionális döntésen alapuló vállalatfelvásárlás növelni fogja az ajánlattevô és a céltársaság együttes értékét, és így a részvényesek javára szolgál. De a két társaság együttes értékében beálló ilyen növekedés még nem jelenti önmagában azt, hogy a tranzakció hatékony. Egy ilyen következtetés szükségszerúen csak akkor lehet igaz, ha a céltársaság és az ajánlattevố részvényeseinek juttatott haszon valós társadalmi hasznot jelent. Bebchuk ugyanakkor az általa megfigyelt vállalatfelvásárlásokból azt a következtetést vonta le, hogy az ajánlattevố és a céltársaság részvényesei számára juttatott egyéni elônyök nem szükségszerúen jelentenek társadalmi hasznot. Bizonyos esetekben a két társaság együttes értékében beálló növekedés a vállalatirányítás tökéletesítésébốl vagy szinergiákból adódik, mely esetekben a megszerzett egyéni hasznok valós társadalmi hasznot is jelentenek egyúttal. Ugyanakkor ez szintén fakadhat adómegtakarításokból (adóoptimalizáló vállalatfelvásárlás) vagy éppen a megnövekedett piaci erôből, mely esetekben, Bebchuk professzor szerint, az egyéni hasznok az adóbevételek vagy a fogyasztók rovására jelenhetnek meg. Alkalmasint pedig a két társaság együttes értékében beálló növekedés a munkavállalók kárára megszerzett hasznot jelképezhet. Így álláspontja szerint egyes akvizíciók társadalmilag nemkívánatosak lehetnek még úgy is, hogy növelik az ajánlattevố és a céltársaság együttes értékét (Bebchuk, 1985:1793).

1988-ban Shleifer és Vishny ${ }^{15}$ professzorok arra a következtetésre jutottak, hogy az ellenséges vállalatfelvásárlások során jelentkezó értékátruházás kérdésének megoldása e tranzakciók veszteseinek kompenzálásán keresztül történhet meg (ShleiferVishny, 1998:15-19; McDaniel, 1991:129-130).

A vállalatfelvásárlások egyéb érdekeltekre - különösen munkavállalókra - gyakorolt hatásairól több empirikus kutatás is napvilágot látott, ugyanakkor ezek jellemzóen nem általános jelleggel fókuszáltak a vállalatfelvásárlásokra, hanem csak egy-egy tranzakciótípust vagy viszonylag szúk mintát elemeztek ebból a szempontból. ${ }^{16}$ Bár e kutatások meglehetôsen vegyes eredményre vezettek (Li, 2012:444-445), általánosságban 
elmondható, hogy a munkavállalói aggályok nem tûnnek megalapozatlannak. A vállalatfelvásárlások ugyanis inkább hátrányosan érintik a munkavállalókat. Erre utal például Li17 2012-ben publikált (széles mintát átfogó) kutatása (Li, 2012:443-460) vagy az Európai Unió viszonylatában a The Takeover Bids Directive Assessment Report összefoglaló adatai (EC, 2012:344-345). A munkavállalókra gyakorolt hatás ugyanakkor csak egy (bár talán legjobban kézzelfogható) elemét jelenti a vállalatfelvásárlások egyéb érdekeltekre gyakorolt hatásának (Halász, 2015:270-274).

\section{A VÁllalatFelVÁSÁRLÁSOK UNióS SZABÁLYOZÁSA ÉS AZ EGYÉB ÉRDEKELTEK VÉDELME}

A vállalatfelvásárlások uniós szabályozásának egyéb érdekeltek védelmére irányuló rendelkezéseit átfogóan elemzi a már említett, az Európai Bizottság megbízásából készített The Takeover Bids Directive Assessment Report. ${ }^{18}$ Így a 2004/25/EK (vállalatfelvásárlási) irányelv idevonatkozó szabályozási rendszerének áttekintéséhez érdemes e dokumentumot segítségül hívnunk.

Az irányelvben már az általános elvek szintjén is megjelenik az egyéb érdekeltek védelmével összefüggésben álló követelmény. Az irányelv 3. cikk (1) bekezdés b) pontja alapján a céltársaság értékpapírjainak birtokosai számára elegendô idôt és információt kell biztosítani ahhoz, hogy megfelelően megalapozott döntést tudjanak hozni az ajánlatról; amennyiben a céltársaság ügyviteli vagy irányító szerve az értékpapír birtokosait tanáccsal látja el, ismertetnie kell az ajánlatnak a foglalkoztatásra, az alkalmazási feltételekre és a társaság üzletviteli helyére gyakorolt hatásait (EC, 2012).

Az irányelv konkrét szabályozása az egyéb érdekeltek közül leginkább a munkavállalói érdekekre helyezi a hangsúlyt. Így az ajánlattétel során közzéteendô ajánlati dokumentációnak is van a munkavállalók szempontjából releváns tartalma. Az irányelv 6. cikk (3) bekezdés i) pontja alapján ugyanis az ajánlati dokumentáció részét képezik az ajánlattevônek a céltársaság és - amennyiben ezt az ajánlat érinti - az ajánlattevô társaság jövóbeni üzleti tevékenységére, munkavállalóik és vezetôik állásainak fenntartására vonatkozó szándékai, beleértve minden, a foglalkoztatás feltételeiben bekövetkezô lényeges változtatást, és különösen az ajánlattevônek a két társaságra vonatkozó stratégiai terveit (Kecskés, 2013:368-376) és a foglalkoztatásra, valamint a társaságok telephelyeire gyakorolt valószínúsíthetô következményeket. Az ajánlat kapcsán közzétett dokumentumokat (így például a vételi ajánlatot, annak módosításait, a vételi ajánlattal kapcsolatban a céltársaság ügyvezető/irányító testületének álláspontját) szintén közölni kell a céltársaság munkavállalói képviselőivel vagy - ilyen képviselôk hiányában - magukkal a munkavállalókkal. ${ }^{19}$ Az irányelv 9. cikk (5) bekezdése pedig kiemeli, hogy a céltársaság ügyviteli vagy irányító szerve elkészíti és közzéteszi a jelentését, amely tartalmazza az ajánlatra vonatkozó, indoklással ellátott véleményét. Ennek keretében kitér az ajánlat végrehajtásának a társaság érdekeire - és különösen a foglalkoztatásra - gyakorolt hatásaira, valamint tartalmazza az ajánlattevónek a céltársasággal kapcsolatos stratégiai terveire vonatkozó nézeteit, és ezeknek a foglalkoztatottságra és a társaság telephelyeire gyakorolt valószínú következményeit. A cél- 
Halász Vendel: Az egyéb érdekeltek jogi védelme az Európai Unió vállalatfelvásárlási...

társaság ügyviteli vagy irányító szerve ugyanekkor közli e véleményt a munkavállalók képviselóivel vagy - ilyen képviselôk hiányában - a munkavállalókkal. Amennyiben a céltársaság a munkavállalók képviselőitôl megfelelő idóben az ajánlatnak a foglalkoztatottságra gyakorolt hatásaira vonatkozó különvéleményt kap, ezt a véleményt a jelentéshez csatolják (EC, 2012). Szintén megjelenik az irányelv szabályozásában, hogy a munkavállalók tájékoztatását, információhoz való hozzáférési lehetôségeik biztosítását ebben az esetben is minimális garanciának tekinti a közösségi jogalkotó a munkavállalók védelmében. Az irányelv 14. cikke kifejti ugyanis, hogy az irányelv nem érinti az ajánlattevô és a céltársaság munkavállalói képviselőinek tájékoztatására és a velük való konzultációra irányadó nemzeti szabályokat, valamint - ha a tagállamok így rendelkeznek - az ajánlattevố és a céltársaság munkavállalóinak a döntésben való részvételével kapcsolatos nemzeti szabályokat.

Továbbá a munkavállalók érdekeit a céltársaság ügyviteli vagy irányító szerve képviseli (illetve kellene képviselnie), mivel a munkavállalók nem rendelkeznek a társaságban önálló döntéshozatali hatáskörrel. Ugyanakkor komolyan megkérdôjelezhetô e rendszer hatékonysága a munkavállalók érdekeinek képviseletében (Sjafjell, 2010:15). A végső döntéshozatali jogkör ugyanis a céltársaság igazgatótanácsának vagy éppen a céltársaság részvényeseinek kezében van egy vállalatfelvásárlás sorsát illetôen. Nincs garancia azonban arra, hogy az igazgatók és részvényesek figyelembe szándékozzanak venni a munkavállalók védelmének szempontjait a vállalatfelvásárlások során (EC, 2012).

Az általános (munka)jogi szabályozás szintén gyakran biztosíthat bizonyos további védelmet a munkavállalók számára. Így például szükséges lehet konzultálni az üzemi tanáccsal vagy a munkavállalói képviselókkel a vállalatfelvásárlási ajánlat vagy annak lebonyolítása kapcsán. Mindazonáltal az általános jogi szabályozás alkalmazása nehézségekbe ütközhet a vállalatfelvásárlások esetében. Így például az ajánlattételt megelőző időszakban az ajánlatra vonatkozó információk bizalmas jellege, az ajánlati időszakban pedig az arra vonatkozó idóbeli megkötések jelenthetnek akadályt (EC, 2012).

A vállalatfelvásárlási irányelv munkavállalókat védó rendelkezéseinek tényleges végrehajtásával kapcsolatban felmerültek bizonyos aggályok az elemzés szerint. Egyes esetekben előfordult ugyanis, hogy a munkavállalói képviselôket nem értesítették megfelelô módon és idóben egy vállalatfelvásárlási ajánlatról, illetve a számukra nyújtott információ nem volt kielégítő. Ennek eredményeként bizonyos tagállamok esetében (például az Egyesült Királyságban) úgy túnt, hogy a munkavállalói jogok ténylegesen kevéssé érvényesülnek. Ez pedig egy valós megfelelôségi problémát vet fel az irányelv rendelkezéseivel kapcsolatban (EC, 2012:102). Egy másik jelentôs probléma, hogy a munkavállalóknak nyújtott információk csak korlátozottan mennek át elôzetes felülvizsgálaton, és gyakorlatilag az ajánlatot követôen semmilyen kikényszeríthetôséggel nem rendelkeznek. Ez konkrétan azt jelenti, hogy bár a munkavállalóknak nyújtott információkat ellenôrizhetik az ajánlattételt megelőzően jó néhány tagállam szabályozása alapján (például Belgiumban, Franciaországban, ${ }^{20}$ Olaszországban, Németországban ${ }^{21}$ a felügyeleti hatóság megvizsgálja az ajánlati dokumentációt), nem érvényesül számonkérhetôség a sikeres ajánlatot követôen. Így az ajánlattevô esetle- 
gesen elmulaszthat a korábbi állásfoglalásának megfelelően eljárni, vagy eltérhet a korábbi terveitôl. Továbbá még ha egy elôzetes ellenôrzés érvényesül is az ajánlattételi dokumentáció kapcsán, ez inkább egy formális ellenőrzést takar, mely az adott információk feltüntetésére korlátozódik, és nem terjed ki az ajánlattevô valós szándékának vizsgálatára (EC, 2012:102-103).

A munkavállalók védelmének áttekintését követôen indokolt megvizsgálni az irányelv által a munkavállalók körén kívül esố érdekelteknek biztosított védelmet. Ennek kapcsán - a dokumentum gondolatmenetét követve - idézhetjük az irányelv 3. cikk (1) bekezdés c) pontját. Ez általános elvként kimondja, hogy a céltársaság ügyviteli vagy irányító szervének a társaság mint egész érdekében kell eljárnia, és nem tagadhatja meg az értékpapír birtokosaitól az ajánlat érdemi megítélésének lehetôségét. Az irányelv 3. cikk (1) bekezdés c) pontja alapján arra lehet következtetni, hogy a „társaság érdekei” nem egyeznek meg a részvényesek érdekeivel, hiszen különben nem lenne indokolt ezeket külön is megemlíteni. A társaságra, „mint egészre” történó hivatkozás pedig egy széles körú megközelítésre enged következtetni. Arra utal, hogy a társaságra mint minden érdekeltje érdekeinek képviselőjére kell tekinteni. Az irányelv bár nem ad konkrét meghatározást az érdekeltek koncepciójára, de alapvetôen kétféle megközelítést sugalmaz. Egyrészt a munkavállalók sorolhatóak ide, akik az irányelv számos rendelkezésében megjelennek. Másrészt idetartozhatnak a helyi közösségek, melyeket az irányelv 9. cikk (5) bekezdése említ, mikor a „társaság telephelyeire” hivatkozik. A „társaság egészébe” beletartozó más érdekek tipikusan magukban foglalhatják a hitelezôi érdekeket, a szerződéses partnereket (pl. alvállalkozók, beszállítók) és a közhivatalokat/ hatóságokat. A környezetet szintén idesorolhatjuk, legalább abban a terjedelemben, amíg érinti a munkavállalókat vagy a helyi közösségeket (EC, 2012:104). A „társaság mint egész" fogalom konkrét meghatározásának, kibontásának hiányán túl azonban az irányelv arra sem ad magyarázatot, hogy a részvényesek és az egyéb érdekeltek érdekei között felmerüló érdekkonfliktust hogyan lehetne feloldani. Az irányelv 3. cikk (1) bekezdés c) pont alapelvi szintú szabályozása egy arányossági tesztet igényelne az ajánlattétel kapcsán az igazgatók magatartására irányadó két szabály között. Egyrészt ugyanis a „társaság mint egész” érdekében kell eljárniuk, másrészt nem tagadhatják meg az értékpapírok birtokosaitól az ajánlat érdemi megítélésének lehetôségét (EC, 2012:105).

A céltársaság menedzsmentjének magatartására ugyanakkor - mint fent kifejtettem - fôszabályként a semlegességi szabály rendelkezései irányadók, így nem tehetnek védekező intézkedéseket egy meggyôződésük szerint a „társaság mint egész” számára hátrányos ajánlattal szemben. Így alapvetôen a részvényesi döntéshozatal elve fog érvényesülni, melyet erôsen befolyásolhat a vállalatfelvásárlással együtt járó rövid távú nyereség lehetősége, amellyel szemben más szempontokat vélhetően kevésbé vesznek számításba. Az irányelv 9. cikkének átültetését mellőzô tagállamok viszont hangsúlyt helyezhetnek az igazgatótanács kötelességére a társaság érdekének megvédésében. Ezzel párhuzamosan pedig feltehetôen kevesebb figyelmet fordítanak e tevékenység részvényesi jogokra gyakorolt esetleges hatására (EC, 2012:105). A „társaság mint egész” érdekének figyelembevételére ez alapján azon tagállamok esetében nyílhat lehetôség, amelyek nem alkalmazzák a 2004/25/EK irányelv semlegességi szabályát. Ilyen tagál- 
lam például Dánia, Németország, Magyarország, Hollandia, Lengyelország, Belgium és Luxemburg (EC, 2012:190). E tagállamokban az igazgatótanácsoknak alapvetôen a „társaság mint egész érdekében” kellene fellépniük vállalatfelvásárlási helyzetekben. Ennek keretében lehetôség nyílhatna a részvényesi érdekek figyelembevétele mellett akár az ezen túlmutató, egyéb érdekeltek érdekeinek figyelembevételére is. Fontos kérdés azonban, hogy mit tekint konkrétan az irányelv a „társaság mint egész” érdekébe tartozónak, milyen érdekek vehetôk figyelembe? Erre az irányelv megfogalmazásából csak távoli következtetés vonható le, mely feltehetốn nem lenne elégséges jogi alapja a beavatkozásnak. Tehát mivel az irányelv, és jellemzóen a tagállami jogalkotás is (Halász, 2016:698-707), adós maradt a "társaság mint egész érdeke” fogalom tartalmával, így nincs szilárd felhatalmazás az egyéb érdekeltek érdekeinek figyelembevételére. Ezért az egyéb érdekeltek érdekei nem tudnak számottevô súllyal megjelenni az Európai Unióban zajló vállalatfelvásárlások során (Halász, 2015:280-290).

\section{ZÁRÓGONDOLATOK}

A gazdaságban és a társasági szférában kulcsfontosságú a profit, mint a befektetések megtételére ösztönzô alapvetố tényezô, és a felelôs gazdálkodás eredménye (ZémanTóth-Bárczi, 2008:485-491; Lukács-Tóth-Zéman, 2012:106-117). Ezért a részvényesek (befektetốk) érdekeit védô szabályoknak véleményem szerint is kiemelt részét kell képezniük a gazdasági jogi szabályozásnak, így a vállalatfelvásárlási jognak is. Emellett viszont nem tarthatom helyesnek, hogy a részvényesi jólét, a profit maximalizálására irányuló törekvések egyéb, nem részvényesi érdekeltek esetleges jelentôs érdeksérelmével valósuljanak meg. Az (ellenséges) vállalatfelvásárlások és szabályozásuk területén ezt azért hangsúlyozom, mert az ilyen ügyletek nagy részében a részvényesek jelentôs (legalábbis rövid távon jelentkezô), biztos hozamra tudnak szert tenni. ${ }^{22}$

A részvényesi érdekek védelmén túlmenően, a vállalatfelvásárlási ügyletek szabályozása során indokolt figyelmet fordítani a társaságban jelen lévô más érdekcsoportok, egyéb érdekeltek helyzetére is. Önmagában nem megnyugtató (és társadalmi értelemben hasznos ${ }^{23}$ ) az, ha ezen ügyletek nyertesei (jellemzôen a céltársaság részvényesei) többet nyernek, mint amennyit az esetleges vesztesek veszítenek. John C. Coffee profeszszor is pontosan megfogalmazta ennek egyik okát: nevezetesen, hogy a vállalatfelvásárlás során a nyertesek számánál mind helyi, mind nemzeti szinten nagyobb lehet a vesztesek száma. A részvényesek ugyanis viszonylag kevesen vannak az egyéb érdekeltekhez viszonyítva (Coffee, 1990:1548). És amíg a vesztesek jellemzóen helyben jelennek meg (helyi, nemzeti szinten), addig a nyertesek a globális tôkepiacok korában szétoszlanak a világ minden tájára (McDaniel, 1991:129-130). Olyan vállalatfelvásárlási tranzakciókat kell tehát célul kitúzni, és a szabályozásnak az olyan vállalatfelvásárlási tranzakciókat kell elôsegítenie, melyek valós társadalmi hasznot jelentenek. Amennyiben a hozam alapvetôen más, nem részvényesi érdekeltek rovására realizálódik, akkor ezek az ügyletek jellemzôen nem jelentenek egyúttal valós gazdasági és társadalmi hasznot. ${ }^{24}$ Így véleményem szerint a szabályozás szintjén nem érdemes ezek létrejöttét bátorítani. Sôt, a felmerült érdekkonfliktusokat társadalmilag is megnyugtató módon kellene feloldani. 


\section{Polgári Szemle · 13. évfolyam 1-3. szám}

\section{JEGYZETEK}

1 E körbe tartoznak például a hitelezôk, a munkavállalók, valamint akár a helyi közösségek is. Lásd: KECSKÉS, 2008:215-234.

2 2004/25/EK irányelv 5. cikk (1), 5. cikk (4).

3 2004/25/EK irányelv 2. cikk (1) e) fogalommeghatározása.

4 Felhatalmazással kell rendelkezni legalább attól az idôponttól kezdődôen, hogy a céltársaság tudomást szerez az ajánlattételrôl szóló döntésrốl, addig, amíg az ajánlat eredményét közzé nem teszik, vagy az ajánlat hatályát nem veszti. A tagállamok megkövetelhetik, hogy a felhatalmazás megszerzésére korábban kerüljön sor, például amint a céltársaság ügyviteli vagy irányító szerve értesül az ajánlattételre irányuló szándékról. Lásd 2004/25/EK irányelv 9. cikk (2) második albekezdés.

5 A semlegességi szabály, tehát az irányelv 9. cikk (2), (3) bekezdése alkalmazása alól.

6 Ugyanez a mentesítés adható meg az ún. áttörési szabály alkalmazása alól, mely az irányelv 11. cikkében található.

7 A semlegességi szabályt átültetố tagállamok: Ausztria, Bulgária, Ciprus, Csehország, Észtország, Finnország, Franciaország, Görögország, Írország, Olaszország, Lettország, Litvánia, Málta, Portugália, Románia, Szlovénia, Szlovákia, Spanyolország és az Egyesült Királyság. Lásd EC, 2012:3.

8 A helyi közösségeknek jelentôs érdekeltségük fưzôdik a területükön múködô társasághoz. Így egyrészt jelentôs költségvetési bevételük származhat innen, másrészt számos helyi munkavállalónak nyújthatnak megélhetést, harmadrészt az adott területen múködô társaságok gyakran folytatnak karitatív tevékenységet, vagy tesznek adományokat, mely a közösség elônyére válik. A hatások természetesen lehetnek pozitívak és negatívak is. A helyi közösségek éppen ezért fontosnak tartják, hogy a környezetükben múködố vállalkozások környezetbarát és társadalmilag felelôs módon végezzék tevékenységüket. Lásd Zhao, 2014:9-16.

9 Ugyanakkor elképzelhetô ennél kiterjesztôbb értelmezése is az egyéb érdekeltek körének. Például Robert Gray professzor és szerzôtársai idesorolták az eljövendó generációkat és a nem emberi élőlényeket is. Lásd Rahim, 2011:307; Gray-Owen-Adams, 1996:1-332.

10 Ezen álláspontra helyezkedik például John C. Coffee. Lásd Coffee, 1990:1495-1550; Coffee, 1986:1-109; Coffee, 1988:435-466; Shleifer-Summers, 1988:33-56.

11 Richard A. Booth a Villanova University, Widger School of Law üzleti jog professzora.

12 Andrei Shleifer a Harvard Egyetem közgazdaságtan-professzora.

13 Lawrence H. Summers a Harvard Egyetem professzora és emeritus elnöke. 1999 és 2001 között az Amerikai Egyesült Államok pénzügyminisztere (elôtte 1995-tôl 1999-ig annak helyettese).

14 Lucian A. Bebchuk a Harvard University jog, gazdaságtan és pénzügyek professzora, a Program on Corporate Governance igazgatója.

15 Robert W. Vishny a University of Chicago Booth School of Business pénzügyek professzora.

16 A vállalatfelvásárlási irányelv hatásait elemzô The Takeover Bids Directive Assessment Report szintén utal arra, hogy a vállalatfelvásárlások munkavállalókra gyakorolt hatását illetôen empirikus bizonyítékok csak szúkösen állnak rendelkezésre. A vonatkozó empirikus kutatásoknak számos akadályt kell ugyanis leküzdeniük (pl. a megfelelố kontrollcsoport kiválasztása, az akvizíciókból és a társaság feldarabolásából adódó munkavállalóilétszám-változás elkülönítése az organikus változásoktól stb.). Lásd EC, 2012.

17 Li Xiaoyang a Cheung Kong Graduate School of Business (CKGSB) adjunktusa közgazdaságtan és pénzügyi területen.

18 A dokumentum elkészítésében a Marccus Partners (Mazars Group) és a Centre for European Policy Studies (CEPS) vett részt az Európai Bizottság megbízásából. EC, 2012.

19 Lásd 2004/25/EK irányelv 6. cikk (2). Az irányelv 8. cikk (2) bekezdése szintén rögzíti a tagállamok arra vonatkozó kötelezettségét, hogy biztosítsák, ezen dokumentumok a céltársaság és az ajánlattevô munkavállalóinak képviselôi, illetve - ilyen képviselők hiányában - a munkavállalók számára könnyen és gyorsan hozzáférhetôk legyenek. EC, 2012.

20 A francia felelôss társaságirányításról lásd Kecskés, 2016:301-310.

21 A német felelôs társaságirányításról lásd Kecskés-Ferencz, 2017:107-125.

22 Vö. Cremers et al., 2009:1409-1410; Anjier, 1991:586-587; Fitzgibbon, 2010:57; Jensen, 1988:21-22. 
${ }^{23}$ A haszonelvúségrôl és a hasznosságról Jeremy Bentham és John Austin is sokat értekeztek. Lásd Kecskés, 2007:345-351; valamint Kecskés, 2006:113-127; Kecskés, 2015:465-479.

24 Vö. Bebchuk, 1985:1693-1808, 1792; McDaniel, 1991:129.

\section{FELHASZNÁLT IRODALOM}

Anjier, John C. (1991): Comments-Anti-takeover Statutes, Shareholders, Stakeholders and Risk. Louisiana Law Review, vol. 51, no. 3.

Bebchuk, Lucian A. (1985): Toward Undistorted Choice and Equal Treatment in Corporate Takeovers. Harvard Law Review, vol. 98, no. 8.

Bebchuk, Lucian A. (2002): The Case Against Board Veto in Corporate Takeovers. The University of Chicago Law Review, vol. 69, no. 3., https://doi.org/10.2307/1600639.

Berglöf, Erik - Burkart, Mike (2003): European Takeover Regulation. Economic Policy, vol. 18, no. 36., https://doi.org/10.1111/1468-0327.00105.

Booth, Richard A. (1989): State Takeover Statutes Revisited. Michigan Law Review, vol. 88, no. 1., https:// doi.org/10.2307/1289138.

Brown, Frank W. (1970): Comments-Corporate Defenses to Takeover Bids. Tulane Law Review, vol. 44, no. 3.

Brudney, Victor - Chirelstein, Marvin A. (1974): Fair Shares in Corporate Mergers and Takeovers. Harvard Law Review, vol. 88, no. 2.

Chatterjee, Sayan - Harrison, Jeffrey S. - Bergh, Donald D. (2002): Failed Takeover Attempts, Corporate Governance and Refocusing. Strategic Management Journal, vol. 24, no. 1., 87-96., https://doi. org/10.1002/smj.279.

Coffee, John C. (1984): Regulating the Market for Corporate Control: A Critical Assessment of the Tender Offer's Role in Corporate Governance. Columbia Law Review, vol. 84, no. 5., https://doi. org/10.2307/1122351.

Coffee, John C. (1986): Shareholders Versus Managers: The Strain in the Corporate Web. Michigan Law Review, vol. 85, no. 1., https://doi.org/10.2307/1288884.

Coffee, John C. (1988): The Uncertain Case for Takeover Reform: An Essay on Stockholders, Stakeholders and Bust-Ups. Wisconsin Law Review, no. 3.

Coffee, John C. (1990): Unstable Coalitions: Corporate Governance as a Multi-Player Game. Georgetown Law Journal, vol. 78 , no. 5 .

Cremers, Martijn K. J. et al. (2009): Takeovers and the Cross-Section of Returns. The Review of Financial Studies, vol. 22, no. 4.

EC (2007): Report on the Implementation of the Directive on Takeover Bids. Staff Working Document, Commission of the European Communities, http://ec.europa.eu/internal_market/company/docs/ takeoverbids/2007-02-report_en.pdf.

EC (2012a): The Takeover Bids Directive Assessment Report. European Commission, http://ec.europa.eu/internal_market/company/docs/takeoverbids/study/study_en.pdf.

EC (2012b): Report from the Commission to the European Parliament, the Council, the European Economic and Social Committee and the Committee of the Regions. European Commission, $\operatorname{COM}(2012) 347$ final, http:// ec.europa.eu/internal_market/company/docs/takeoverbids/COM2012_347_en.pdf.

Edwards, Vanessa (2004): The Directive on Takeover Bids. European Company and Financial Law Review, vol. 1, no. 4., https://doi.org/10.1515/ecfr.2004.1.4.416.

Enriques, Luca (2004): The Mandatory Bid Rule in the Takeover Directive. Harmonization Without Foundation? European Company and Financial Law Review, vol. 1, no. 4., https://doi.org/10.1515/ ecfr.2004.1.4.440.

Ferrarini, Guido - Miller, P. Geoffrey (2009): A Simple Theory of Takeover Regulation in the United States and Europe. Cornell International Law Journal, vol. 42, no. 3.

Fitzgibbon, Tiernan (2010): An Analysis of the Takeover Code's Treatment of an Acquiring Company's Shareholders; Stealing From the Rich to Give to the Already Wealthy? King's Student Law Review, vol. 2, no. 2. 


\section{Polgári Szemle · 13. évfolyam 1-3. szám}

Fontanella-Khan, James - Massoudi, Arash (2015): Global dealmaking breaks 2007 record. Financial Times, www.ft.com/content/ccb6f428-a7d0-11e5-955c-1e1d6de94879.

Goergen, Marc - Martynova, Marina - Renneboog, Luc (2005): Corporate Governance Convergence: Evidence From Takeover Regulation Reforms (2005 April). European Corporate Governance Institute, ECGI - Law Working Paper, No. 33/2005, http://papers.ssrn.com/sol3/papers.cfm?abstract_id=709023.

Gray, Rob - Owen, Dave - Adams, Carol (1996): Accounting and accountability: Changes and challenges in corporate social and environmental reporting. Prentice Hall.

Halász Vendel - Kecskés András (2011): Társaságok a tốzsdén. HVG-ORAC, Budapest.

Halász Vendel (2015): Érdekek és értékek az Európai Unió és az Egyesült Államok vállalatfelvásárlási szabályozásában. Doktori értekezés, Pécsi Tudományegyetem, Pécs, http://pea.lib.pte.hu/bitstream/handle/ pea/15664/halasz-vendel-phd-2016.pdf?sequence=1\&isAllowed=y.

Halász Vendel (2016): A „társaság érdeke”: a vállalati vezetôk tevékenységére irányadó szabályokról Európában és Amerikában. Magyar Jog, 63. évf., 12. sz., 698-707.

Hannes, Sharon (2003): The Hidden Virtue of Antitakeover Defenses. Cardozo Law Review, vol. 24, no. 5.

Jensen, Michael C. (1988): Takeovers: Their Causes and Consequences. Journal of Economic Perspectives, vol. 2, no. 1., https://doi.org/10.1257/jep.2.1.21.

Kecskés András (2006): John Austin gondolatai a jogról, a jogon kívüli tényezôkrốl és a szankciókról. In: Tanulmányok dr. Földvári József professzor 80. születésnapja tiszteletére. Szerk. Gál István László, Hornyák Szabolcs, Pécsi Tudományegyetem, Állam- és Jogtudományi Kar, Pécs.

Kecskés András (2007): John Austin félig megélt élete és félig megírt jogbölcselete. Jogtudományi Közlöny, 62. évf., 7-8. sz.

Kecskés András (2008): Részvényárak mindenek felett? Érdekszférák a vállalatirányítás jogában. In: Emlékkönyv Román László születésének 80. évfordulójára. Szerk. Kiss György, Berke Gyula, Bankó Zoltán, Kajtár Edit, PTE Állam- és Jogtudományi Kar, Pécs.

Kecskés András (2011): A tôzsdei társaságok tulajdonosi szerkezete. Európai Jog, 11. évf., 6. sz.

Kecskés András (2013): Stratégiai döntések és motivációs elméletek az ellenséges vállalatfelvásárlások tekintetében. Jogtudományi Közlöny, 68. évf., 7-8. sz.

Kecskés, András (2015): Inside and Outside the Province of Jurisprudence. Rechtstheorie, vol. 46, no. 4.

Kecskés András (2016): Franciasaláta - felelôs társaságirányítás francia módra. Jogtudományi Közlöny, 71. évf., 6. sz.

Kecskés András - Halász Vendel (2013): Stock Corporations. A Guide to Initial Public Offerings, Corporate Governance and Hostile Takeovers. HVG-ORAC-LexisNexis, Budapest-Wien.

Kecskés András - Bujtár Zsolt (2016): Számok búvöletében: kérdôív a felelôs társaságirányításról. Jura, 21. évf., 2. sz.

Kecskés András - Ferencz Barnabás (2017): Szirénhangok a Rajnán. Iustum Aequum Salutare, 13. évf., 1. sz.

Li, Xiaoyang (2012): Workers, Unions and Takeovers. Journal of Labor Research, vol. 33, no. 4., 443-460.

Lukács János - Tóth Márk - Zéman Zoltán (2012): A számviteli politika döntéstámogatásának modellezése ágazati mátrix fejlesztéssel. Gazdaság és Társadalom, 4. évf., 3-4. sz.

Magnuson, William (2009): Takeover Regulation in the United States and Europe: an Institutional Approach. Pace International Law Review, vol. 21, no. 1.

Massoudi, Arash - Fontanella-Khan, James (2016): M\&A boom set to continue in 2017. Financial Times, December 29, www.ft.com/content/0e9afdce-cdb6-11e6-b8ce-b9c03770f8b1.

McCord, Thomas J. (1984): Limiting Defensive Tactics in Tender Offers: A Model Act for the Protection of Shareholder Decisionmaking. Harvard Journal on Legislation, vol. 21, no. 2.

McDaniel, Morey W. (1991): Stockholders and Stakeholders. Stetson Law Review, vol. 21, no. 1.

Menjucq, Michel (2006): The European Regime on Takeovers. European Company and Financial Law Review, vol. 3, no. 2., https://doi.org/10.1515/ecfr.2006.009.

Oyedele, Akin (2016): Here's what 10 Wall Street pros are predicting for the stock market in 2017. Business Insider, www.businessinsider.com/stock-market-outlook-for-2017-2016-12.

Rahim, Mia Mahmudur (2011): The „Stakeholder Approach” to Corporate Governance and Regulation: An Assessment. Macquarie Journal of Business Law, vol. 8. 
Halász Vendel: Az egyéb érdekeltek jogi védelme az Európai Unió vállalatfelvásárlási...

Romano, Roberta (1992): A Guide to Takeovers: Theory, Evidence, and Regulation. Yale Journal on Regulation, vol. 9, no. 1 .

Shleifer, Andrei - Summers, Lawrence H. (1988): Breach of Trust in Hostile Takeovers. In: Corporate Takeovers. Causes And Consequences. Ed. A. Auerbach, University of Chicago Press.

Shleifer, Andrei - Vishny, Robert W. (1998): Value Maximization and the Acquisition Process. Journal of Economic Perspectives, vol. 2, no. 1.

Sjafjell, Beate (2010): The Core of Corporate Governance: Implications of the Takeover Directive for Corporate Governance in Europe. UCD Working Papers in Law, Criminology \& Socio-Legal Studies Research Paper No. $27 / 2010$.

Tuchinsky, Dmitry (2016): The Takeover Directive and Inspire Art: Reevaluating the European Union's Market for Corporate Control in the New Millenium. New York Law School Law Review, vol. 51, no. 3.

Zéman Zoltán - Tóth Márk - Bárczi Judit (2008): Az ellenôrzési tevékenység kialakítási folyamatának modellezése a kiegészítô melléklet tartalmának összefüggésében, különös tekintettel a gazdálkodási tevékenységeket érintô K+F és innovációk elszámolására. Bulletin of the Szent István University, Special Issue.

Zhao, Jingchen (2014): The Curious Case of Stakeholder Theory: Calling for a More Realistic Theory. International Trade and Business Law Review, vol. 17, no. 1.

Zinser, Alexander (2003): Einer neuer Anlauf: der jüngste Vorschlag einer Übernahmerichtlinie vom 2.10.2002. Europaisches Zeitschrift für Wirtschaftrecht, Bd. 14., no. 1.

Zwecker, Andrew (2012): The EU Takeover Directive: Eight Years Later, Implementation but Still no Harmonization among Member States on Acceptable Takeover Defenses. Tulane Journal of International and Comparative Law, vol. 21, no. 1. 